\title{
CENTRUM-PERIFÉRIA KÉRDÉSEK A NEMZETKÖZI MIGRÁCIÓBAN
}

\author{
(Centre-periphery Issues in International Migration)
}

\author{
KINCSES ÁRON - RÉDEI MÁRIA
}

\begin{abstract}
Kulcsszavak:
centrum-periféria nemzetközi vándorlás kistérség regionális elemzés

A cikk célja egyfelöl bemutatni a migráció kérdését a centrum és periféria vonatkozásában, másfelöl a nemzetközi ki- és bevándorlás nemek szerinti centrum és periféria arányainak elemezése a hazai kistérségek szintjén az ezredfordulót követö idöszakban. A szerzők célja kettös felhasználást kívánt megalapozni, részben a kistérségi népesség-elöreszámítások megbizhatóságát növelni, részben a migrációs stratégia regionális elemeit támogatni.
\end{abstract}

\section{A centrum-periféria elmélet és modellje}

A centrum-periféria fogalompárt I. Wallerstein a modern világgazdaság történelmi analízisében használja. A benne használt tartalmak nemcsak a társadalmi szervezödés makroszintjére vonatkoznak, hanem a helyi gazdaság struktúrájára is értelmezhetők. Ö valójában nem is az említett szélső elemekre fókuszált, hanem a közöttük lévő viszonyra. Wallerstein szerint a centrum, mint relatív központ és a periféria, mint peremi helyzet között függőségi kapcsolat van. Az ő megfogalmazásából alig tünik ki ennek a dinamikus volta. Véleményünk szerint ez a viszony, különösen a mobilitás esetére nézve, dinamikus közvetítőnek fogható fel; ami lehet egy- és többirányú áramlás, amely vonzó és taszító elemeken alapszik. A vonzás iránya, mértéke összefügg a térbeli elérhetőséggel, a földrajzi helyzettel, a gazdasági és kulturális potenciállal, valamint a döntéshozatali, irányítási erőviszonyokkal. A centrumperiféria modellt csupán egy évtizeddel előzte meg a függetlenség elmélete, mondható, hogy ebböl nőtt ki.

A függetlenség gazdasági elmélete azt mondja ki, hogy a szegény országok természeti erőforrásokkal, olcsó munkaerővel és a máshol már leváltásra ítélt technológia üzembe helyezésével képesek kapcsolódni a világhoz. Ezzel hozzájárulnak a gazdag országok fejlődéséhez. Ez a változás közvetítéssel valósul meg. A fejlett országok ezt a relációs helyzetet a pénzügyi szolgáltatásokon, a médián, a politikai kapcsolatok ápolásán, és az emberi erőforrásokon, az oktatáson, a kultúrán keresztül erősítik meg. Mindebbe beleértve a munkaerő toborzását, képzését, áthelyezését és a technológiai átadáshoz kapcsolódó eljárások ismeretének gyakorlatát is. Ha szükséges, a fejlett országok ezt a helyzetet gazdasági, de akár katonai eszközökkel is fenntartják. 
A függetlenségi elmélet alkalmazói azt állítják, hogy a perifériák fejlődése olyan átmenetben következik be, hogy nem közvetlenül a világ mintáiba, standardjaiba kapcsolódnak be, hanem másolni igyekeznek azt, ami a közeli központjukban látható. Ez az ún. lépcsőzetes alkalmazkodás, tanulás, ami a migrációs folyamatokra oly jellemző. Egy migrációs esemény megvalósulásával kezdődik el az új környezetbe való beilleszkedés. Ennek következménye az, hogy egyesek elfogadják az itteni szokásokat, elégedetten élnek, míg mások nem, és ekkor új helyet keresnek. Ezzel az álláspontjukkal megkérdőjelezik a szabadáramlás elméletét (Wallerstein 1979; 1991).

Wallerstein visszautasította a harmadik világ kifejezést, és azt állította, hogy egyetlen világ létezik, amely összehasonlítható, az előnyös és hátrányos vonások mérhetők, amelyek a versenyt indukálják. A centrum olyan társadalmi-gazdasági formációt jelent, amely fejlettségét tekintve a kor élvonalában foglal helyet. Fejlődése autonóm, az innováció az adott rendszer belső szerkezetéből és a népesség belső motiváltságából következik be. A periféria társadalma a centrum fejlettségi szintjétől elmaradt, leszakadt formációt képez, és felzárkózása közeli mintakövetésen alapul (Tamás 1990).

A szociológia a függetlenség elméletét gyakorta értelmezi, miszerint a folyamatot átélő személyek a jövőben a külső körülmények módosulásától függő magatartást fognak mutatni. A demográfusok például azért alkalmazzák a kohorsz jellemzőket a távlati kitekintések során, mert ezzel tudják igazolni azt, hogy az egymást követö születési évjáratok akár ugyanabban a térségben is eltérően képesek viselkednek.

\section{A centrum-periféria viszony az ezredfordulón}

A II. világháború utáni fél évszázadban lényeges változások következtek be a világgazdaságban, melyek a tőke, a munkaerő, az áru és a szolgáltatás áramlásával valósultak meg. A technikai fejlődés és a térbeli elérhetőség javulása lehetővé tette azt, hogy ezek gyorsan, sokszor alig látható módon történjenek.

A centrum-periféria viszony megváltozott tartalma a migráció globális vonatkozásában részben a gyarmati rendszer összeomlására vezethető vissza, ami több lényeges következménnyel járt. Például, a gyarmati országok függetlenné váltak, de nem önállóvá. A korábbi gyarmatok kapcsolatban maradtak az anyaországgal, ami pl. erős, többnyire a centrumba irányuló migrációs vonzást jelentett.

A világ migrációs célpontjait jelentő országokban az információgazdaság megerösödése, az ezt kiszolgáló magas színvonalú humántőke-állomány jelentős koncentrációja figyelhető meg. A gazdasági-müszaki tevékenységek közül a centrum országok keretein belül marad, és azok nagyvárosaiban összpontosul a kutatófejlesztő tevékenység, a globális üzletpolitikát meghatározó tevékenységek köre, az információs, kutatási, felsőoktatási tevékenység (Hannerz 1992).

Az ágazati szerkezetben egyre jelentősebb helyet foglalnak el a tercier szektor korszerü ágazatai (bank-, pénzügyi, biztosítási stb. szolgáltatások) és az információ- 
gazdaság. Az ipar olyan ágazatai maradnak fenn, amelyek növekvő mértékben magasan kvalifikált szellemi tőkét és fajlagosan csökkenő energiát, nyersanyagot igényelnek, és ennek megfelelően kibocsátásukban a „high-tech”-t megtestesítő korszerü technológiák, magas müszaki színvonalat képviselö termékek a dominánsak (Jakobi 2007). A periféria országainak, régióinak gazdasági és tevékenységi szerkezete ennek a fordítottja.

Krugman „új gazdaságföldrajza”, illetve a feldolgozóipari átrendeződés a világban (Krugman 1991) példát mutatnak arra, hogy az összehasonlításon alapuló, ún. komparatív előnyök miként alakulnak át együttműködésekké, ún. kooperatívvá, majd formálódik a verseny, azaz a viszony kompetitívvé válik. A stratégiai fontosságú ipar hoszszabb üzleti értékelést követően a központokban valósul meg, és csak később indukál térségi átrendeződést. Például kisebb hozzáadott értékủ beszállítói hálózattal bővüinek, vagy társ- és alközpontokat alakítanak ki és ezek profilja válik irányadóvá.

A nemzetközi népességmozgások egyik jellemzője az, hogy az adatokat a fogadó országok oldalán tudjuk a legjobban megismerni. Következésképpen a statisztikai adatok megbízhatósága itt a legjobb. Ez is erősíti a centrumok helyzetét. A célországnak érdeke az érkezők minél teljesebb megismerése. Kevés példa található arra, hogy adatokkal rendelkezünk az ún. honnan-hová migrációs láncról (KincsesTakács 2010). A migrációs láncelemzések nagymértékben hozzájárulnak a földrajzi távolság, a társadalmi háttér alapján a jövőbeli migráció valószínüsítéséhez, ami a népesség elöreszámítások egyik alapozó kérdése.

Ismeretes a migrációs döntések elemzésével foglalkozó kutatásokból az, hogy a migránsok azt a helyet keresik, ahol történik valami, ahol kedvezőbb feltételek várják, és feltételezésük szerint ezek a pólusok. Az érkezés helye szerinti elemzések erösítették meg azt, hogy a városi térségek állnak az érdeklődés középpontjában. Ez összefüggésbe hozható azzal, hogy itt találhatók a lehetőségek, már korábban ide települt baráti, nemzetiségi, rokoni kapcsolatok alapján, és azt is megerősítik a felvételek, hogy a szabadosabb környezet is ebben közre játszik. A magasan képzettek esetén, akik irányítói, felhasználói, kutatói vagy fejlesztői tevékenységet látnak el, többnyire a városi térségek kerülnek szóba ${ }^{1}$.

A városok arculata, sokszínüsége, a kulturális áramlatokban betöltött szerepe kapcsolódik a centrum-periféria kérdéséhez. A migráció kultúra közvetítő és hoszszan ható folyamat. Többnyire az érkezők és a már ott élők közötti aszimmetriák vannak jelen a gondolkodásban, a társadalom szerveződésében. A központ/periféria viszony szerkezetének egy másik jellemzöje lehet a sok kapcsolódó elem. Azzal, hogy a küldők és a befogadók száma növekszik, nemcsak a földrajzi kiterjedés nő, de a célterületeken a kulturális diverzitás is (Benton-Short-Price 2007). Továbbá, ha valaki fel akarja vázolni a világ jelenlegi kulturális áramlatainak térképét, nyilvánvalóan fel kell tennie azt a kérdést is, hogy: milyen mértékủ a perifériák visszahatása, ami a migráció esetében nagyjából egyenértékủ azzal a kérdéssel, hogy milyen hatást gyakorol a harmadik világ a nyugati társadalmakra. Ez azt fejti ki, hogy a tudás-centrumok és azt ottani végzettség vagy tevékenység milyen vonzást jelent és mennyire referencia értékü. 
A globalizáció újratermeli az egyenlötlenséget, a jövedelmek, a funkciók terén. Az új tevékenységek gyorsan központokat teremthetnek, amelyek sokszor tiszavirág életủek, vagy az információs társadalom eszközeivel tér és idő függetlenekké válhatnak. A migráció folyamatos követése azért is kiemelten fontos, hogy ezekre a vállalati áthelyezésekre adatokat kapjunk. Egyes tevékenységek számára mindegy, ahogy azok hol helyezkednek el a világban, csak müködjenek. Ezen tevékenységekben olyan embereket foglalkoztatnak, akik magasan és speciálisan képzettek. Más tevékenységekben éppen a szemtől-szembe kapcsolat válik döntővé. A magasan képzettek nemcsak ide igyekeznek és helyzetbe kívánnak kerülni, hanem éppen olyan gyorsan váltanak új helyszínre és akár magukkal is viszik azokat az ismereteket, amelyek a müködést, a fejlesztést jelentik. Ezen példák is megerősítik azt, hogy a stratégiák egyik meghatározó törekvése a kohézió, a felzárkózás. Nemes Nagy azt összegzi (Nemes Nagy 1996), ami a területfejlesztési politikának az alapvető célja. A törekvés a kiegyenlítésre irányul, kezelni az egyenlötlenséget. A migrációs politika ilyet nem fogalmaz meg.

Az elmúlt időszak globális migrációjának egyik alapvető jellemzője az volt, hogy a célországok száma növekedett, míg a forrás országok szinte az egész világra kiterjedtek. Ezt nevezi a migrációs irodalom diverzitásnak, ami a sokféle kultúra, nyelv és egyéb jellemzők alapján aggódik a beilleszkedést illetően. Ritka példa az, amikor a centrum iránti érdeklődés korlátozásával kívánják megőrizni a sokszínü összetételt. Például az Amerikai Egyesült Államokban szeretnék ezt a diverzitást megőrizni, ezért korlátozzák egy-egy országból érkezők arányát.

A tanulási célú migráció jól értelmezhető centrum-periféria helyzeteket mutat. Globálisan a folyamat földrajzilag koncentrált, meghatározott országokat érint. (Salt-Miller 2006; Rédei 2009). Az országokban is meghatározott városokba, campusokba irányul. Hasonló helyzet állapítható meg a hazautalás tekintetében is, ahol a centrumból kerül átutalásra az összeg a perifériákra. Azok, akik átmenetileg vagy tartósan a centrumokba kerültek, keresetük megélhetésen felüli részét hazautalják. A hazautalások mértéke a FDI-vel azonos és behálózza a világot. Ez az otthonnal, mint perifériával egy folyamatos kapcsolattartó elemnek minősül.

Tehát a nemzetközi migráció globális, nemzeti és kistérségi, területi szinten számos példát mutat arra, hogy a centrum-periféria kapcsolatok jelen vannak.

\section{A nemzetközi be-és kivándorlás alakulása hazai kistérségi szinten}

A migráció területén a központ és környéke kérdésében lényeges a vonzás, a közvetítés. Kutatásunkat több dolog motiválta; egyfelől a kárpát-medencei migrációs alapkutatás egyik üzenete az volt, hogy az átjárható határokkal alapvetően megváltozott a határ menti régiók helyzete, felértékelődtek és kontaktzónákká váltak (Nemes Nagy 1996). Másfelől, a nemzetközi migráció területi hatásainak elemzése során, de még inkább annak várható előrejelzésekor szükségessé vált a kistérségi centrumok és perifériájuk nemzetközi migrációs érintettségének elemzése. 
Elemzésünk a KSH nemzetközi migráció településszintű adatait dolgozta fel kistérségi szinten a 2000-2007 időszakra, kiemelve a kistérségek centrum településeit.

Az 1. táblázatból az állapítható meg, hogy bevándorlók 78,1\%-a, a kivándorlók 78,8\%-a a kistérségi centrumokkal kerül kapcsolatba. Az ezredforduló óta ennek mértéke a bevándorlók körében 81,39-76,14\% között változott. A kivándorlók körében 84,83-73,83\% arányok között változott, de minden esetben a centrumok ,,bonyolították le" a forgalom meghatározó részét. Ez azt jelenti, hogy a kistérségi népesség előretekintések, csupán centrum településre alapozott adatai nagy megbízhatósággal alkalmazhatók. Fokozottan igaz ez a kisebb szórást mutató bevándorlás esetére. A nemek szerinti különbség a bevándorlók esetében 8 év adatainak átlagában 1,74\%, a kivándorlók esetében $2,23 \%$, de mindkét folyamat esetében a férfiak többlete jellemző.

\section{TÁBLÁZAT}

Nemzetközi vándorlási áramlások százalékos megoszlása Magyarországon kistérségi centrum-perifériák szerint összesen, 2000-2007

(Distribution of International Migration Flows in Hungary by Centers-peripherals Situations of Subregions, 2000-2007)

\begin{tabular}{|c|c|c|c|c|c|}
\hline \multirow{2}{*}{ Nemek szerint } & \multirow{2}{*}{$\dot{E} v$} & \multicolumn{2}{|c|}{ Bevándorló } & \multicolumn{2}{|c|}{ Kivándorló } \\
\hline & & periféria & centrum & periféria & centrum \\
\hline \multirow{9}{*}{ Férfi } & 2000 & 21,36 & 78,64 & 12,88 & 87,12 \\
\hline & 2001 & 22,56 & 77,44 & 18,53 & 81,47 \\
\hline & 2002 & 19,40 & 80,60 & 19,41 & 80,59 \\
\hline & 2003 & 17,70 & 82,30 & 24,60 & 75,40 \\
\hline & 2004 & 21,15 & 78,85 & 19,24 & 80,76 \\
\hline & 2005 & 23,50 & 76,50 & 20,29 & 79,71 \\
\hline & 2006 & 19,99 & 80,01 & 17,83 & 82,17 \\
\hline & 2007 & 22,57 & 77,43 & 26,92 & 73,08 \\
\hline & Átlagosan & 21,13 & 78,87 & 20,37 & 79,63 \\
\hline \multirow{9}{*}{ Nő } & 2000 & 23,47 & 76,53 & 19,38 & 80,62 \\
\hline & 2001 & 25,29 & 74,71 & 18,40 & 81,60 \\
\hline & 2002 & 21,24 & 78,76 & 21,94 & 78,06 \\
\hline & 2003 & 19,87 & 80,13 & 28,10 & 71,90 \\
\hline & 2004 & 23,56 & 76,44 & 21,74 & 78,26 \\
\hline & 2005 & 24,04 & 75,96 & 21,59 & 78,41 \\
\hline & 2006 & 22,12 & 77,88 & 19,58 & 80,42 \\
\hline & 2007 & 22,46 & 77,54 & 27,58 & 72,42 \\
\hline & Átlagosan & 22,87 & 77,13 & 22,60 & 77,40 \\
\hline \multirow{9}{*}{ Összesen } & 2000 & 22,40 & 77,60 & 15,17 & 84,83 \\
\hline & 2001 & 23,86 & 76,14 & 18,47 & 81,53 \\
\hline & 2002 & 20,21 & 79,79 & 20,44 & 79,56 \\
\hline & 2003 & 18,61 & 81,39 & 26,05 & 73,95 \\
\hline & 2004 & 22,22 & 77,78 & 20,20 & 79,80 \\
\hline & 2005 & 23,73 & 76,27 & 20,75 & 79,25 \\
\hline & 2006 & 20,93 & 79,07 & 18,45 & 81,55 \\
\hline & 2007 & 22,52 & 77,48 & 27,17 & 72,83 \\
\hline & Átlagosan & 21,90 & 78,10 & 21,23 & 78,77 \\
\hline
\end{tabular}

Forrás: Saját szerkesztés. 
Magyarországon találhatók olyan kistérségek, ahol a centrum-periféria arányok jelentősen eltérnek a jellemző 20-80\%-tól. A vándorlások a Balaton környékén (Öriszentpéteri, Balatonföldvári, Keszthelyi stb. kistérségek) és a román határ közelében (Hajdúhadházi, Bodrogközi, Mezőkovácsházai, Füzesabonyi stb. kistérségek) főként az adott térség perifériájára irányul. Az előbbit a Balaton térségében megjelenő nyugat-európai nyugdíjasok (Illés 2008) által óhajtott vidéki környezettel, az utóbbit a határ román oldalán, onnan nem messze élő vidéki magyar népesség áttelepülésével magyarázhatjuk. Azaz, ezeknek a migráns csoportoknak egyértelmüen ezek a térségek vonzóak a természetföldrajzi értékek, vagy éppen a megszokott környezet és a családdal történő könnyebb kapcsolattartás miatt, ezekben az esetekben a döntéseikben nem a gazdasági érdekek játsszák a főszerepet. A másik oldalról, egyrészt Magyarországon elsődlegesen Budapesten és a megyeszékhelyvárossal rendelkező kistérségekben (Debreceni, Pécsi, Békéscsabai, Szegedi stb.) él a külföldiek többsége, másrészt ezekben a térségekben a centrumban történik a legnagyobb arányú migráns ki- és beáramlás. Azaz, itt elsődlegesen a gazdasági okokkal magyarázhatók a mozgások, a migránsok számára a nagyobb városok válnak elsődleges célpontokká (Rédei 2007). Összefoglalva, azok között a kistérségek között, ahová az elmúlt 8 év alatt bevándorlás volt a jellemző, találhatunk centrum, köztes vagy perifériális területeket is, a vándorlás motivációjától függően.

\section{1. ÁBRA}

A centrumterületek kistérségenkénti \%-os részesedése a bevándorlók kumulált értékei között, 2000-2007

(The Share of Centres of Subregions by Cumulative Values of Immigrants, 2000-2007)

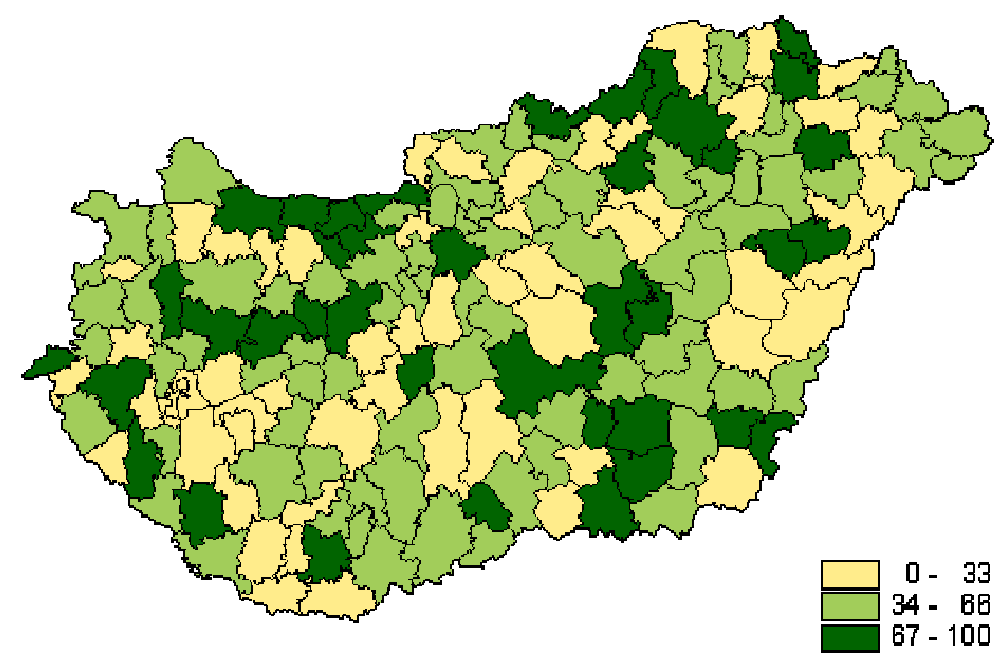

Forrás: Saját szerkesztés. 
A bevándorlás és a kivándorlás térségeinek egyenlegéből, érintettségéből megállapítható az is, hogy egyes térségek nem képesek helyben tartani a külföldieket, a migránsok nem kötődnek a területhez (1. és 2. ábra). Noha nem tudjuk olyan részletesen követni a folyamatokat, hogy azt tudjuk igazolni, hogy ugyanazon migráns személyek be és kifelé irányuló mozgásáról van-e szó ${ }^{2}$. Idetartoznak az M8 sz. út menti térségek, az északi Duna mente, Szentgotthárd, Paks, Dél-Zala, Budapest, Sajó mente, Szolnok, Kecskemét, Makó, Orosháza, Gyula, Békéscsaba, ahol a fluktuáció mértéke magas.

\section{2. ÁBRA}

A centrumterületek kistérségenkénti \%-os részesedése a kivándorlók kumulált értékei között, 2000-2007

(The Share of Centres of Subregions by Cumulative Values of Emigrants, 2000-2007)

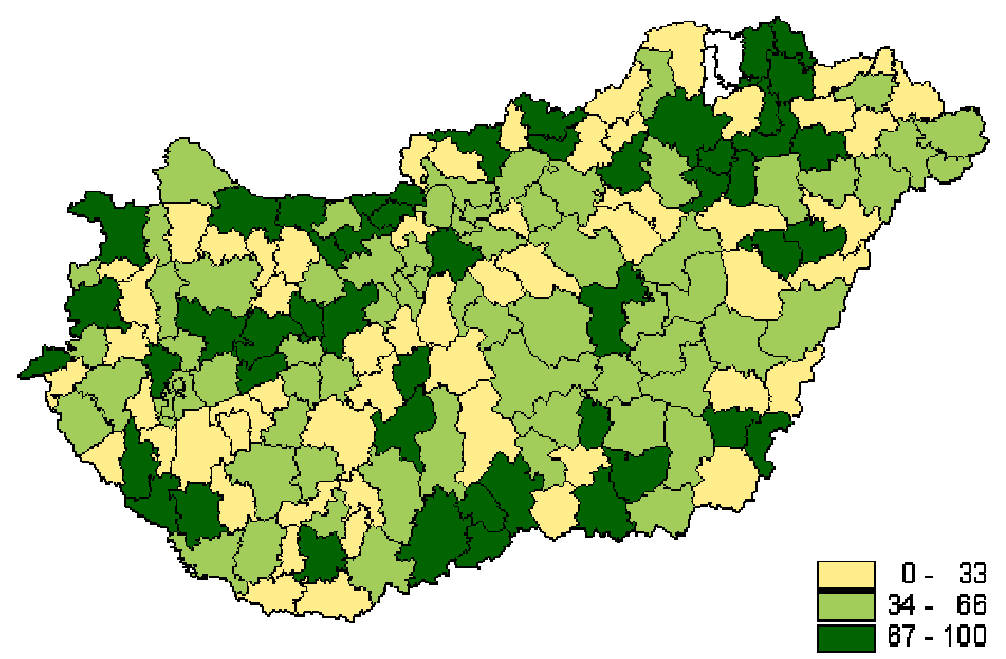

Forrás: Saját szerkesztés.

Amennyiben a 2001 és 2008 évek közötti átlagos be-, illetve kivándorlások által az előző két térképen kialakított alacsony (0-33\%), közepes (34-66\%) és magas (67-100\%) kistérségeken belüli centrum arányokat a külföldiek 2008. január 1-jei állapotának megfelelö iskolai végzettségekkel és korcsoportokkal hasonlítjuk össze, még egyértelmüvé válik, hogy más-más motivációjú, demográfiai, gazdasági tulajdonságokkal rendelkező migránsokat találhatunk a kialakított csoportokban (3. és 4. ábra). Pontosabban azt láthatjuk, hogy azokban a kistérségekben, ahol a migránsok többsége a centrumba vándorol, ott magasabbak az iskolai végzetségek és több a munkaképes korú, mint a másik két csoportban. Ezek az externális összetételbeli jellemzők hosszú távon hozzák kedvezményezett helyzetbe a centrumokat. A 4. ábra arra is utal, hogy a legjobbakat nem képes megtartani. 


\section{3. ÁBRA}

Bevándorló külföldiek megoszlása a területi csoportok és iskolai végzettségek $(18-X)$ szerint

(Distribution of Immigrants by Spatial Groups and Educational Attainments [18-X])

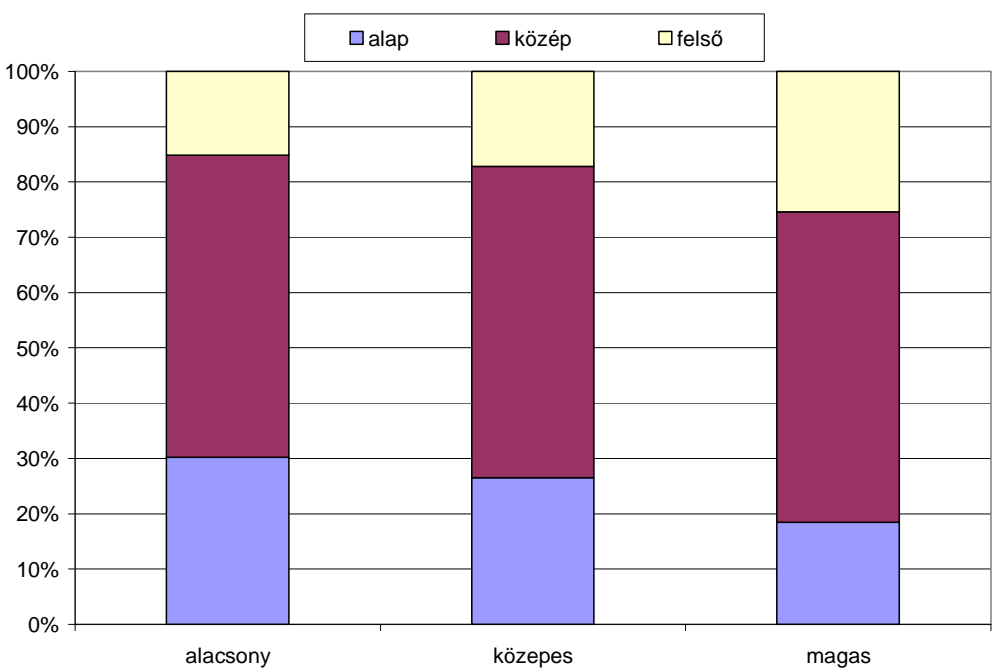

Forrás: Saját szerkesztés.

\section{4. ÁBRA}

Kivándorló külföldiek megoszlása a területi csoportok és iskolai végzettségek (18-X) szerint

(Distribution of Emigrants by Spatial Groups and Educational Attainments [18-X])

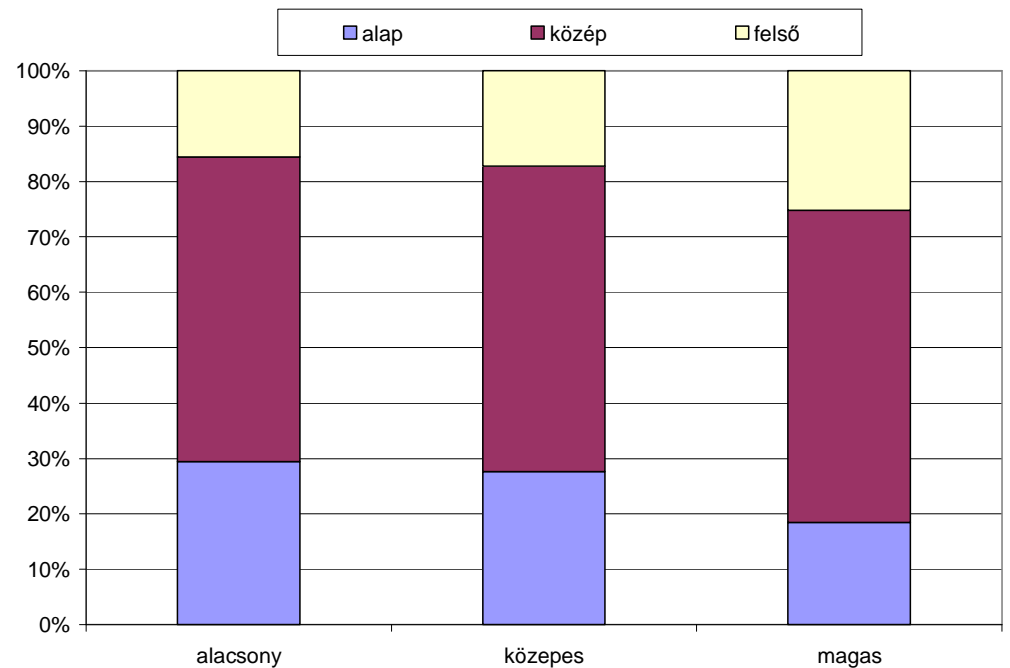

Forrás: Saját szerkesztés. 


\section{5. ÁBRA}

Bevándorló külföldiek megoszlása a területi csoportok és korcsoportok szerint (Distribution of Immigrants by Spatial Groups and Age Groups)

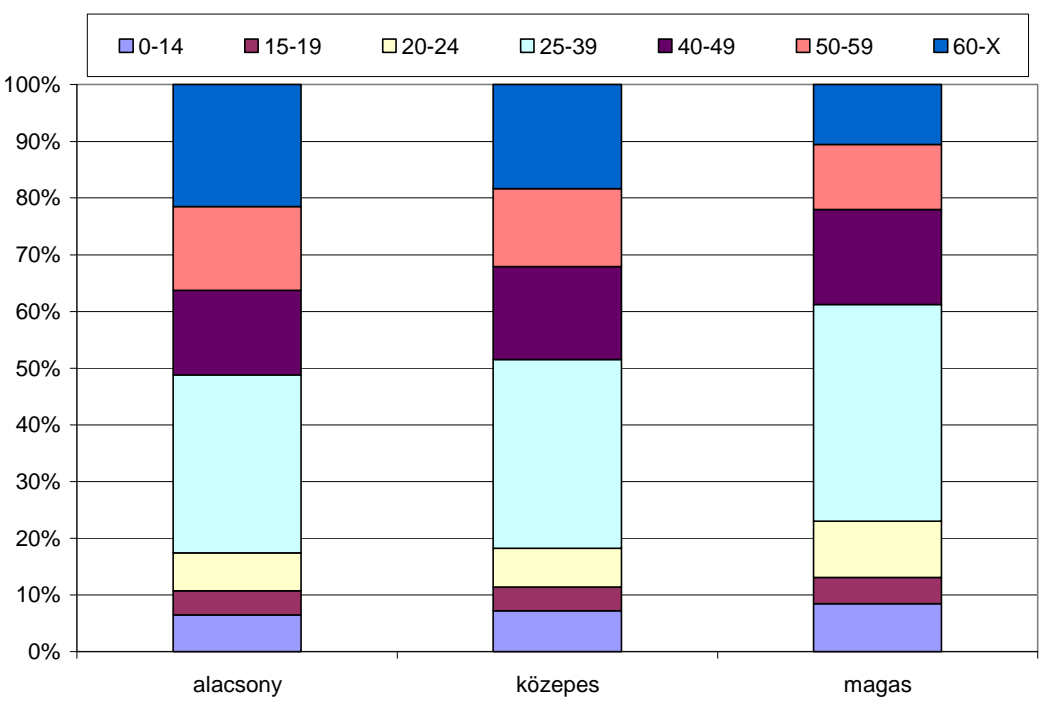

Forrás: Saját szerkesztés.

\section{6. ÁBRA}

Kivándorló külföldiek megoszlása a területi csoportok és a korcsoportok szerint (Distribution of Emigrants by Spatial Groups and Age Groups)

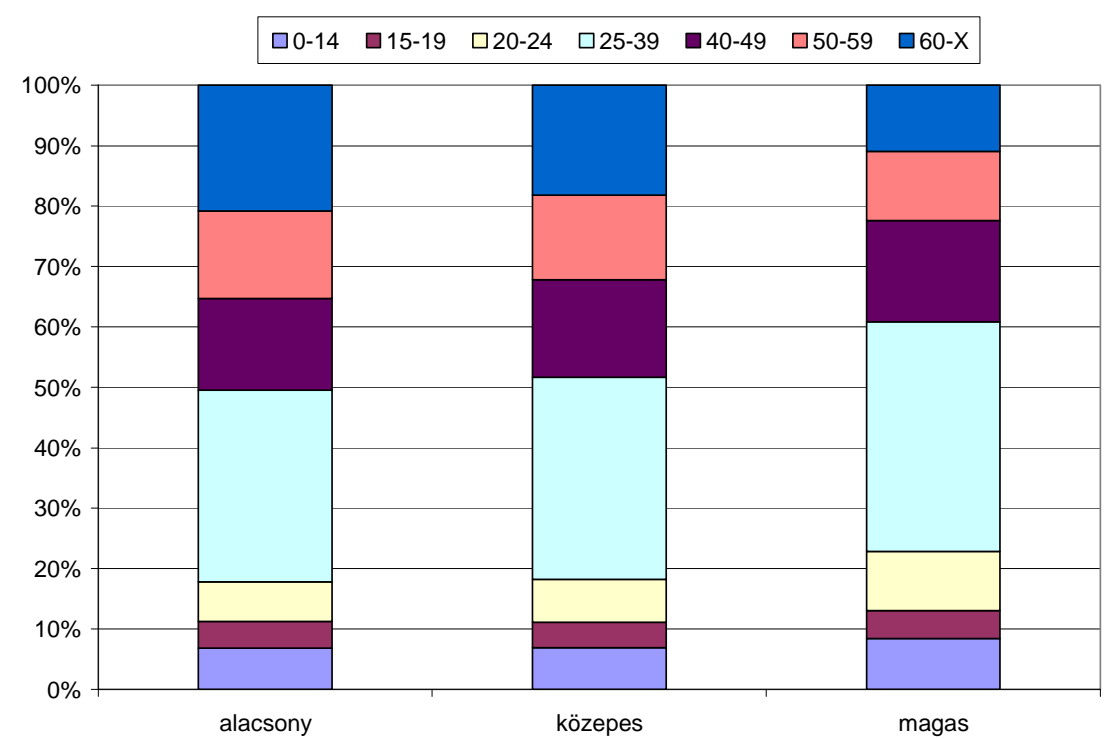

Forrás: Saját szerkesztés. 
Az 5. és 6. ábra azt bizonyítja, hogy a magas migrációs érdeklődést mutató centrumok nem tartják meg a fiatalokat. A nyugdíjaskorúak kevésbé a centrumokba igyekeznek. Mindez a népesedési helyzetre is hosszú távon hatással van.

Végezetül azt összegezhetjük, hogy Magyarországon is a centrum települések négyszer akkora vonzást, illetve taszítást gyakorolnak, mint a periférián lévő települések. Ezzel hozzájárulnak egy térségi szintű előretekintés nagyobb valószínüségű megbízhatóságához. Igazoltuk, hogy vannak olyan térségeink, amelyek nem tartják meg az odaérkezőket. A folyamat az elmúlt 8 év során alig változott, a ki- és befelé irányuló mozgás jellemzői e tekintetben alig különböznek. A férfiak lakóhelyválasztása térben koncentráltabb. Tény, hogy a centrumokba letelepedő lakosság iskolai végzettsége, életkori jellemzői kedvezőbbek, mint a perifériára érkezőké, és ez különösen igaz azokban a kistérségekben, amelyek a migrációs érdeklődés homlokterében állnak.

\section{Jegyzetek}

${ }^{1}$ http://international.metropolis.net/index_e.html

${ }^{2}$ A migrációs irodalom gyökértelenek címszó alatt foglalkozik a kérdéssel (Marrus 1985).

\section{Irodalom}

Benton-Short, L.-Price, M.D. (2007) Immigrants and World Cities: From the Hyper-Diverse to the Bypassed. - GeoJournal. 68. 103-117. o.

Hannerz, U. (1992) Cultural Complexity: Studies in the Social Organization of meaning. Columbia University Press, New York.

Illés S. (2008) Indirect estimation on the types of international elderly migration in Hungary. Romanian Review on Political Geography. 1. 55-63. o.

Jakobi Á (2007) Hagyományos és új elemek az információs társadalomban. PhD értekezés, ELTE, Budapest.

Kincses Á.-Takács Z. (2010) Szerb állampolgárok Magyarországon. - Terïleti Statisztika. 2. 182-197. o.

Krugman, P. (1991) Increasing Returns and Economic Geography. - Journal of Political Economy. 483-499. o.

Marrus, M. (1985) Uprooted unwanted immigrants. Oxford University Press, Oxford.

Nemes Nagy J. (1996) Centrumok és perifériák a piacgazdasági átmenetben. - Földrajzi Közlemények. 1. 31-48. o.

Rédei M. (2009) Tanulmányi célú mozgás. Reg-Info kiadó, Budapest.

Rédei M. (2007) Mozgásban a világ, a nemzetközi migráció földrajza. Eötvös Kiadó, Budapest.

Salt, J.-Miller, J. (2006) In whose interests? IT migration in an interconnected world economy. Population, Space and Place. 13. 41-58. o.

Tamás P. (1990) Centrum periféria viszonyok a tudományban. - Jelkép. 4. 16-25. o.

Wallerstein, I. (1979) The Capitalist World-Economy. Cambridge University Press, Cambridge.

Wallerstein, I. (1991) Geopolitics and Geoculture: Essays on the Changing World-System. Cambridge University Press, Cambridge. 